\title{
Determinants of Banks' Profitability: Panel Data from Qatar
}

\author{
Rima Charbaji El-Kassem \\ Social and Economic Survey Research Institute (SESRI), Qatar University, Doha, Qatar \\ Email: rima.charbaji@qu.edu.qa
}

How to cite this paper: El-Kassem, R.C. (2017) Determinants of Banks' Profitability: Panel Data from Qatar. Open Journal of Accounting, 6, 103-111.

https://doi.org/10.4236/ojacct.2017.64009

Received: July 20, 2017

Accepted: August 28, 2017

Published: August 31, 2017

Copyright $\odot 2017$ by author and Scientific Research Publishing Inc. This work is licensed under the Creative Commons Attribution International License (CC BY 4.0).

http://creativecommons.org/licenses/by/4.0/

\section{(c) (i) Open Access}

\begin{abstract}
Purpose: The aim of this paper is to investigate the main determinants of banks' profitability and answer the question "what is the effect of liquidity and risk variables on the explained variation of banks' performance in Qatar?" Design/methodology/approach: A sample of six major lender banks for the period 2008-2015 is retrieved from the worldwide bankscope database. The dependent variable "Return on Average Assets (ROAA)" is taken as a function of independent variables that are basically liquidity and risk variables. Findings: Findings of this study show that variation in the independent variable "Total Capital Ratio \%" positively and significantly affects the explained variation in performance of banks in Qatar measured by "ROAA", while variation in "Cost to Income Ratio", negatively and significantly impacts the variation in performance of banks in Qatar. At the same time, variation in "Reserves for impaired Loans/A nonperforming loan (NPL)" and variation in "Loan to Assets Ratio" significantly and negatively affect ROAA of banks in Qatar. Practical implications. It is recommended to replicate the findings of this study in each of the other GCC country before building an econometric model to cluster the GCC banks into homogeneous segments. Originality: The research problem is based on review of literature and investigation in a novel way using EViews 9 and Panel Data.
\end{abstract}

\section{Keywords}

Profitability, Bank’s Performance, Panel Data, Fixed Effect Model

\section{The Rise of Qatar Banking Sector}

The evolution of Qatar's banking sector from 1949 till now reflects the change and expansion of Qatar's economy. The need for Qatar's banking sector started with the exploration and export of oil that "was discovered in commercial quan- 
tities in Qatar in 1939 and was first exported in 1949" (Middle East Arab, 2010) [1]. Dr Abdulaziz A al-Ghorairi reports that "Until 1954, the Eastern Bank (now Standard Chartered Bank) was the only bank operating in Qatar. With a need to have more banks, the British Bank of the Middle East (acquired by HSBC), the Othman Bank, (formerly Grindlays Bank, acquired by Standard Chartered), and the Arab Bank began operations in Qatar in the 1950s, following by the Lebanese Bank (now Al-Mashrek Bank), in 1960" (Al-Ghorairi, 2016) [2]. Saeed Al-Muharrai reports that "Qatar established its first national bank (known as the Qatar National Bank) in 1965 with joint venture capital shared equally between the Government of Qatar and the public" (Al-Muharrai, 2009: p. 169) [3]. Today, there are more than eighteen banks operating in Qatar supporting Qatar high-growth economy (Arabian Gulf Life, 2016) [4]. Dan Carrol notes that "natural wealth has greatly enhanced the country's international recognition; Qatar is slated to become the first Arab nation to host the FIFA World Cup in 2022. Its standard of living is also expected to continue surging" (Carrol, 2014) [5]. Standard \& Poor's Ratings Services report that "the drop in hydrocarbon prices and the Qatari government's streamlining of its public investment program are putting the brakes on economic growth, banks' asset quality held generally steady while credit growth remained resilient on the back of strong private sector activity in 2015” (Standard \& Poor's Ratings Services, 2016) [6].

\section{Significance of the Study}

The rating agency Moody's predicts economic growth in the GCC region to be positive along with banks' strong profitability in spite of the global financial crisis and the challenging operating banking environment in the GCC. CPI Financial notes that "Moody's Investors Service's stable outlook for 2017 on the banking sectors of the Gulf Cooperation Council (GCC) reflects the rating agency's expectation of their resilience to persistent economic and funding pressures" (CPI Financial, 2017) [7]. The banking editor, Augustine reports that "Lower oil revenues are leading to a decline or slowdown in government and related entity deposits and lower economic growth also means broad reductions in corporate and retail deposit inflows. However, recent international bond and Sukuk issuances from Abu Dhabi, Oman, Qatar and Saudi Arabia have helped to moderate liquidity pressures, and most regional banks maintain strong levels of liquid assets, eligible as collateral at central banks in case of need" (Augustine, 2016) [8]. On the one side, Bocchi assumes that if "natural gas prices remain stable, Qatar will continue to be a fast-growing, rich nation that punches above its weight in global affairs" (Bocchi, 2015) [9]. On the other side, A \& T Bank Economic Research argue that "Like other GCC states, Qatar banking system will face a more challenging environment in the medium term period as the economic slowdown due to slump in hydrocarbon prices and moderate borrowing appetite from the Qatari government and corporate will lead to slower growth in loans and deposits with pressuring sector's profitability" (A \& T Bank Economic 
Research, 2016: p. 1) [10]. Due to the important role that banks can play as part of Qatar national vision 2030 in supporting Qatari Small and Medium Size Enterprises (SMEs), it becomes imperative to evaluate the performance of commercial banks in Qatar especially in view of today's abrupt changes in oil prices and the winning of the bid for the FIFA world cup 2020. The aim of this paper is to investigate the main determinants of banks' performance in Qatar over the period 2010-2015.

\section{Methodology, Variables and Data}

A sample of six major lender banks for the period 2008-2015 is retrieved from bankscope data base, the worldwide database of banks. The starting year 2008 is chosen because Basel II was put into practice prior to 2008. Niemeyer notes that "Following the international financial crisis that started in 2007, many countries have introduced tighter regulations for banks" (Niemeyer, 2016: p. 1) [11]. Most of these regulatory changes are global standards for bank's liquidity and capital adequacy. What is more, it was announced recently by Fitch that bankscope data base was replaced by Orbis Bank Focus on Jan 2017. The samples of six major Qatari banks are: Qatar National Bank, The Commercial Bank (QSC), International Bank of Qatar Q.S.C., Doha Bank, Al Khalij Commercial Bank and Ahli Bank QSC. The dependent variable "Return on Average Assets (ROAA)" shows to what extent the bank's management is efficiently using its assets to generate profits and is used in this study as proxy for bank profitability performance (Goddard et al., 2004 [12]; Athanasoglou et al., 2008 [13]; Kosmidou et al., 2008 [14]; Heffernan and Fu., 2008) [15] taking into consideration that the average annual values of assets (ROAA) better conveys the performance than the end year values of assets(ROA). The independent variables are basically liquidity and risk variables that include: Liquid assets (cash and marketable securities), Gross loans, Loan loss reserves (estimated losses on loans), Bank's loan loss reserves (loan loss provisions), and Net income (bank's total earning), Total capital ratio \%, Cost to income ratio \%, Reserves for impaired loans/NPLs the USD and Loans/Assets \%. Previous research identify the bank size as an inside the bank factor that influences the performance. The effect is not clear. On one hand, bigger size may create economies of scale, thus an enhancement in performance, but at the same time, the bigger size firms are often affected by inflexibility, bureaucracy, that may lower the performance (Kosmidou, 2008 [14]; Athanasoglou et al., 2008 [13]). The natural logarithm of total bank assets is used as proxy for the size. The credit risk is one of the main variables that affect the bank performance, as it show evidence of the loss probability because of the failure of the debtor to meet its obligations to the bank. The literature usually expresses it by the ratio of loan loss reserves to gross or net loans granted by banks. Mansur and associates expect a negative effect on performance of the potential losses from bad quality loans (Mansur et al., 1993) [16]. So the question arises as to what is the effect of liquidity and risk variables on the explained variation in banks' performance in 
Qatar for the period 2008-2015?

\section{Results}

Table 1 shows the growth in Total Assets and Profit after Tax for the six Qatari Banks included in this study:

Not all six banks in Qatar recorded robust growth from 2014 to 2015. On one side, Qatar National Bank was ranked first in terms of growth of total assets while Al Khalij Commercial Bank and Doha Bank were rank in the second and third places. On the other side, Al Khalij Commercial Bank, Ahli Bank QSC, Qatar National Bank and Doha Bank were ranked in the first, second, third and fourth places respectively in terms of profit before tax. The Commercial Bank (QSC) and International Bank of Qatar Q.S.C. showed sluggish performance and negative growth in profit which is not easy to justify. Al-Ghorairi notes that "Qatar, by contrast, appears almost immune to cheap oil. Whilst Qatar is a significant oil producer, it is predominantly a gas exporter and the price of its natural gas exports are only weakly correlated with oil. Qatar's economic performance is expected to remain strong, thanks largely due to the solid expansion in non-hydrocarbon sector and wise fiscal planning" (Al-Ghorairi, 2015) [17].

Table 1. The growth in total assets and profit after tax for the six Qatari banks.

\begin{tabular}{|c|c|c|c|}
\hline Bank Name & Year & Total Assets the USD & Profit before Tax the USD \\
\hline \multirow[t]{3}{*}{ Qatar National Bank } & 2014 & $133,614,484.6$ & $3,072,170.48$ \\
\hline & 2015 & $147,968,990.7$ & $3,297,143.018$ \\
\hline & Growth & 0.107432261 & 0.073229184 \\
\hline \multirow[t]{3}{*}{ Al. Khalij Commercial Bank } & 2014 & $14,077,500.69$ & $159,917.5902$ \\
\hline & 2015 & $15,558,791.97$ & $178,928.5802$ \\
\hline & Growth & 0.105224025 & 0.118879918 \\
\hline \multirow[t]{3}{*}{ Doha Bank } & 2014 & $20,746,594.42$ & $376,428.5898$ \\
\hline & 2015 & $22,887,116.5$ & $378,653.8647$ \\
\hline & Growth & 0.103174624 & 0.005911546 \\
\hline \multirow[t]{3}{*}{ The Commercial Bank (QSC) } & 2014 & $31,772,611.44$ & $546,895.6311$ \\
\hline & 2015 & $33,906,897.26$ & $403,653.8659$ \\
\hline & Growth & 0.067173761 & -0.261917918 \\
\hline \multirow[t]{3}{*}{$\begin{array}{c}\text { International Bank of Qatar } \\
\text { Q.S.C. }\end{array}$} & 2014 & $8,484,093.821$ & $159,175.832$ \\
\hline & 2015 & $8,766,483.945$ & $109,917.5878$ \\
\hline & Growth & 0.033284654 & -0.30945806 \\
\hline \multirow[t]{3}{*}{ Ahli Bank QSC } & 2014 & $8,620,989.432$ & $165,192.3158$ \\
\hline & 2015 & $8,873,352.082$ & $177,939.5691$ \\
\hline & Growth & 0.029273049 & 0.07716614 \\
\hline
\end{tabular}


To address the skewed data in this study, the researcher used Log transformation of the variables as shown in Table 2.

To answer that main research question for this study: What is the effect of liquidity and risk variables on the explained variation in banks' performance in Qatar for the period 2008-2015?

The researcher used panel data methods to estimate the following equation for the fixed effect model:

$$
\mathrm{Y}=\alpha+\beta \mathrm{X}_{1}+\beta \mathrm{X}_{2}+\beta \mathrm{X}_{3}+\beta \mathrm{X}_{4}
$$

where:

$$
\begin{aligned}
& Y \text {-ROAA. } \\
& X_{1}-\text { Log Total Capital Ratio \%. } \\
& X_{2} \text {-Log Cost to Income Ratio \%. } \\
& X_{3}-\text { Log Reserves for Impaired Loans/NPLs the USD. } \\
& X_{4} \text {-Loans/Assets \%. }
\end{aligned}
$$

It is imperative to note here that since the researcher in this study is interested in the relation between banks' performance and the set of independent variables and since the researcher in this study is not interested in change in intercepts and cares about the regression coefficient(s) therefore the researcher assumed the fixed effect model. The statistical hypotheses are:

Ho: All $\boldsymbol{\beta}_{i j}$ weights are zero.

H1: At least one of the $\beta_{i j}$ weights is not zero.

The results of the panel data analysis is shown in Table 3.

Four independent variables significantly impact the variation of "ROAA" for the six banks in Qatar. The F statistic $=19.789$ for testing $R^{2}=0.824$ is highly significant at $\mathrm{P}=0.0000$ indicating that all of the coefficients in the panel data model are different than zero. All of the two-tail P-values (prob) are less than

\begin{tabular}{|c|c|c|c|c|c|c|c|c|}
\hline & $\begin{array}{c}\text { Return on } \\
\text { Average Assets } \\
\text { (ROAA) \%. }\end{array}$ & $\begin{array}{c}\text { Total Capital } \\
\text { Ratio } \% .\end{array}$ & $\begin{array}{l}\text { Cost to } \\
\text { Income } \\
\text { Ratio \%. }\end{array}$ & $\begin{array}{l}\text { Reserves for } \\
\text { Impaired } \\
\text { Loans/NPLs } \\
\text { the USD. }\end{array}$ & Loans/Assets \%. & logtotcapitratio & Logcostincra & $\begin{array}{c}\text { log Reserves } \\
\text { for Impaired } \\
\text { Loans/NPLs } \\
\text { the USD. }\end{array}$ \\
\hline Valid & 48 & 48 & 48 & 48 & 48 & 48 & 48 & 48 \\
\hline Missing & 0 & 0 & 0 & 0 & 0 & 0 & 0 & 0 \\
\hline Mean & 2.10144 & 16.894 & 33.92 & $305,819.039$ & 0.615621143 & 1.2172 & 1.5073 & 5.1382 \\
\hline Skewness & -0.367 & 1.501 & 1.894 & 2.625 & -1.039 & 0.970 & 0.196 & 0.192 \\
\hline $\begin{array}{l}\text { Std Error of } \\
\text { Skewness }\end{array}$ & 0.343 & 0.343 & 0.343 & 0.343 & 0.343 & 0.343 & 0.343 & 0.343 \\
\hline
\end{tabular}
0.05 supporting the hypothesis that each coefficient is different from zero.

\section{Conclusion and Recommendations}

The variation in the independent variable "Total Capital Ratio \%" significantly affects the explained variation in performance of banks in Qatar measured by

Table 2. Descriptive statistics. 
Table 3. The effect of liquidity and risk variables on bank's performance in Qatar during 2008-2015.

\begin{tabular}{|c|c|c|c|c|}
\hline \multicolumn{5}{|c|}{ Dependent Variable: RETURN_ON_AVERAGE_ASSETS } \\
\hline \multicolumn{5}{|l|}{ Method: Panel Least Squares } \\
\hline \multicolumn{5}{|l|}{ Date: $03 / 15 / 17$ Time: $13: 12$} \\
\hline \multicolumn{5}{|l|}{ Sample: 20082015} \\
\hline \multicolumn{5}{|l|}{ Periods Included: 8} \\
\hline \multicolumn{5}{|l|}{ Cross-Sections Included: 6} \\
\hline \multicolumn{5}{|c|}{ Total Panel (Balanced) Observations: 48} \\
\hline \multicolumn{5}{|c|}{ White Cross-Section Standard Errors \& Covariance (d.f. Corrected) } \\
\hline Variable & Coefficient & Std. Error & t-Statistic & Prob. \\
\hline $\mathrm{C}$ & 5.316621 & 1.166040 & 4.559552 & 0.0001 \\
\hline LOGCOSTINCRA & -2.842124 & 0.424332 & -6.697881 & 0.0000 \\
\hline LOGTOTCAPITRATIO & 1.897028 & 0.373915 & 5.073422 & 0.0000 \\
\hline LOGIMP & -0.406702 & 0.126815 & -3.207048 & 0.0027 \\
\hline LOGLOANASSET & -3.958331 & 1.148668 & -3.446019 & 0.0014 \\
\hline \multicolumn{5}{|c|}{ Effects Specification } \\
\hline \multicolumn{5}{|c|}{ Cross-section fixed (dummy variables) } \\
\hline R-squared & 0.824155 & Mean d & dent var & 2.101438 \\
\hline Adjusted R-squared & 0.782507 & S.D. de & ent var & 0.535285 \\
\hline S.E. of regression & 0.249636 & Akaike & riterion & 0.245425 \\
\hline Sum squared resid & 2.368087 & Schwe & terion & 0.635259 \\
\hline Log likelihood & 4.109791 & Hannan & an criter. & 0.392744 \\
\hline F-statistic & 19.78881 & Durbin & son stat & 1.842217 \\
\hline Prob (F-statistic) & 0.000000 & & & \\
\hline
\end{tabular}

"ROAA". Inspecting raw data shows that this ratio which measures the percentage of bank's capital to its risk-weighted assets goes in year 2015 from as low as 13.8\% for Al Khalij Commercial Bank to as high as 16.3\% for Qatar National Bank. In addition, it is interesting to know that this ratio varied in year 2008 from as low as $12 \%$ for Ahli Bank QSC to as high as 30.2\% for Al Khalij Commercial Bank. Moreover, this ratio has never gone during the period 2008-2015 below the $8 \%$ requirement for all banks in this study as dictated by Basel II and Basel III accord for capital adequacy ratio. What is more, findings of this study also support findings of previous research that the impact of Total Capital (Tier 1 and Tier 2) ratio on banks' performance is positive (Petriaa et al., 2015: p. 522) [18] but the impact of Total Capital in this study is found to be stronger than previous research because of using transformation to address skewness of financial ratios. The variation in the second independent variable "Cost to Income Ratio" also significantly and negatively impacts the variation in performance of 
banks in Qatar measured by "ROAA". The lower the cost to income ratio the more the profitability as was explained by previous research (Almazari, 2014: p. 138) [19]. It is interesting to note here that Cost to Income Ratio went from $80 \%$ in year 2008 to $32 \%$ in year 2015 for Al Khalij Commercial Bank and went up from $16 \%$ in year 2011 to $22 \%$ in year 2015 for Qatar National Bank. The researcher in this study believes that banks in Qatar are asked to keep their advanced financial technology and to use them more and more in their communication. This will improve the efficiency of banking operations and decrease their Cost to Income Ratio which in turn will boost up their profitability. What is more, the variation in the third independent variable "Reserves for Impaired Loans/A nonperforming loan (NPL)" also significantly and negatively affects the variation in performance of banks in Qatar measured by "ROAA". As a measure of capital risk and a measure of credit quality of banks, it is well known that not accounting but poor lending is the cause of global financial crisis. Findings of this study support results of previous research that lower loan loss provision be translated into higher profitability. Ul Mustafa and his colleagues note that "Banks with less loan loss provision are perceived to have more safety and such an advantage can be translated into higher profitability" (Ul Mustafa, 2016: p. 781) [20]. The last significant variable in this study that significantly and negatively impact ROAA is the "Loan to Assets Ratio". The negative sign could be intercepted as higher loans means higher risk because the value of the asset to secure the loan is less than the loan or it can be intercepted differently as the result of more competition in the Qatari market. Almarzoqi and his associates believe that "banks subject to stronger competitive pressures may have a higher rate of nonperforming loans, if the increase in the risk-taking incentives from the lender's side overcomes the decrease in the credit risk from the borrower's side" (Almarzoqi et al., 2015: p. 2) [21]. Hence, the researcher in this study interprets the negative sign of "Loan to Assets Ratio" as a result of more competition. The researcher in this study believe that understanding the quality of assets is the heart to assessing the health of the banking industry as a whole and at all times a need exists for more transparency in lending strategy. Future research may investigate the banks' performance in the GCC area. It is recommended to replicates the findings of this study in each of the other GCC country before building an econometric model to cluster the GCC banks into homogeneous segments for possible future vertical and/or horizontal merge.

\section{References}

[1] MidleEast Arab (2010) History of Qatar: The Discovery of Oil http://middleeastarab.com/qa/history-qatar-discovery-oil.html

[2] Al-Ghorairi, A. (2016) The Evolution of Qatar Banking Sector: A Short History. Gulf-Times, Doha.

http://www.gulf-times.com/story/485262/The-evolution-of-Qatar-banking-sector-A -short-hist

[3] Al-Muharrai, S. (2009) Analysis of Competitiveness in Qatar Banking Industry. In- 
ternational Journal of Business Innovation and Research, 3, 168-181.

[4] Arabian Gulf Life (2016) List of Banks in Doha Qatar.

http://www.arabiangulflife.com/list-of-banks-in-doha-qatar/

[5] Carrol, D. (2014) The 5 Fastest-Growing Countries in the World. https://www.fool.com/investing/international/2014/11/24/the-5-fastest-growing-co untries-in-the-world.aspx

[6] Standard \& Poor's Ratings Services (2016) Qatari Banks Face Weakening Profitability in 2016: S\&P. http://www.arabnews.com/economy/news/874476

[7] CPI Financial (2016) Moody's Predicts Stable Outlook for GCC Banking Sector in 2017.

http://www.cpifinancial.net/news/post/38549/moodys-predicts-stable-outlook-for-g cc-banking-sector-in-2017

[8] Augustine, B.D. (2016) GCC Banks Seen Defying Challenges to Remain Profitable. http://gulfnews.com/business/sectors/banking/gcc-banks-seen-defying-challenges-t o-remain-profitable-1.1941878

[9] Bocchi, A.M. (2015) Qatar in the Global Context-Past and Future Trends. http://www.economonitor.com/blog/2015/10/qatar-in-the-global-context-past-andfuture-trend/

[10] A\&T Bank Economic Research (2016) Country Report: Qatar. 1-25. https://www.atbank.com.tr/documents/QATAR\%20-\%20NOVEMBER\%202016.PD $\underline{\mathrm{F}}$

[11] Niemeyer, J. (2017) Basel III-What and Why? http://www.riksbank.se/Documents/Rapporter/POV/2016/2016_1/rap_pov_artikel_ 3_160317_eng.pdf

[12] Goddard, J., Molyneux, P. and Wilson, J. (2004) Dynamics of Growth and Profitability in Banking. Journal of Money, Credit and Banking, 36, 1069-1090. https://doi.org/10.1353/mcb.2005.0015

[13] Athanasoglou, P.P., Brissimis, S.N. and Delis, M.D. (2008) Bank-Specific, Industry-Specific and Macroeconomic Determinants of Bank Profitability. International Journal of Financial Market, Institutions Money, 18, 121-136.

[14] Kosmidou, K., Pasiouras, F. and Tsaklanganos, A. (2008) The Determinants of Banks' Profit in Greece during the Period of EU Financial Integration. Managerial Finance, 34, 146-159. https://doi.org/10.1108/03074350810848036

[15] Heffernan, S. and Fu, M. (2008) The Determinants of Bank Performance in China. Working Paper Series, WP-EMG-03-2008, Cass Business School, City University.

[16] Mansur, I., Zangeneh, H. and Zitz, M.S. (1993) The Association between Banks' Performance Ratios and Market-Determined Measures of Risk. Applied Economics, No. 25, 1503. https://doi.org/10.1080/00036849300000154

[17] Al-Ghorairi, A. (2015) Falling Oil Prices and Its Implications on Qatar's Economy. http://www.gulf-times.com/story/428406/Falling-oil-prices-and-its-implications-on -Qatar-s

[18] Petriaa, N., Capraru, B. and Ihnato, I. (2015) Determinants of Banks' Profitability: Evidence from EU 27 Banking Systems. Procedia Economics and Finance, 20, 518-524.

http://www.sciencedirect.com/science/article/pii/S2212567115001045

[19] Almazari, A.R. (2014) Impact of Internal Factors on Bank Profitability: Comparative Study between Saudi Arabia and Jordan. Journal of Applied Finance \& Banking, 4, 125-140. 
[20] Ul Mustafa, A.R., Ansari, R.H. and Younis, M.U. (2016) Does the Loan Loss Provision Affect the Banking Profitability in Case of Pakistan? Asian Economic and Financial Review, No. 2, 772-783.

[21] Almarzoqi, R., Naceur, S.B. and Scopelliti, A.D. (2015) How Does Bank Competition Affect Solvency, Liquidity and Credit Risk? Evidence from the MENA Countries. IMF Working Papers.

https://www.imf.org/external/pubs/ft/wp/2015/wp15210.pdf 